\title{
ANALISIS IMPLEMENTASI PERATURAN PEMERINTAH NOMOR 33 TAHUN 2012 TENTANG PEMBERIAN AIR SUSU IBU EKSKLUSIF \\ (Studi di Kecamatan Arga Makmur Kabupaten Bengkulu Utara)
}

Oleh:

\section{DOLLY ERLIAN KHEVABETA}

\author{
Dosen Prodi Administrasi Negara Fakultas Ilmu Sosial dan Ilmu Politik \\ Universitas Ratu Samban Bengkulu Utara
}

\begin{abstract}
This study shows that in the implementation of Government Regulation No. 33 Year 2012, the Department of Health always educate health workers in health centers especially midwives about exclusive breastfeeding. This information is passed through the village midwife to the community outreach exclusive breastfeeding and pregnant women. In implementing the Government Regulation No. 33 of 2012 the Department of Health do not have sufficient human and financial resources, while for facilities and material information is already available. Midwives in health centers and village midwives have to implement the commitments well in delivering the program to the public especially exclusive breastfeeding mothers with babies. PHC Arga Makmur already cooperating across sectors and programs to support exclusive breastfeeding programs in Arga Makmur subdistrict. Mothers already know and understand about exclusive breastfeeding and its benefits after being given counseling by midwives Conclusion of research is the implementation of Government Regulation No. 33 Year 2012 on Provision of BMS Exclusive in District Arga Makmur review of aspects of communication, resources, implementing and bureaucracy already done PHC Arga Makmur and mothers already understand about exclusive breastfeeding and its benefits after being given counseling by midwives about exclusive breastfeeding.
\end{abstract}

\section{Keywords : Implementation, Government Regulation, Exclusive Breastfeeding}

\section{PENDAHULUAN}

Pembangunan kesehatan sebagai bagian dari pembangunan nasional diarahkan pada peningkatan kualitas sumber daya manusia dan dilaksanakan guna tercapainya kesadaran, kemauan dan kemampuan untuk hidup sehat bagi setiap penduduk agar dapat meningkatkan derajat kesehatan setinggi-tingginya. Pola pemberian makan terbaik untuk bayi sejak lahir sampai berumur 2 tahun meliputi: (a) memberikan Air Susu Ibu (ASI) kepada bayi segera dalam waktu 1 jam setelah lahir; (b) memberikan hanya ASI saja sejak lahir sampai umur 6 bulan. Hampir semua ibu dapat dengan sukses menyusui diukur dari permulaan pemberian ASI dalam jam pertama kehidupan bayi (Kemenkes, 2012:27-28) 
Program peningkatan penggunaan ASI menjadi prioritas karena dampaknya yang luas terhadap status gizi dan kesehatan anak usia bawah lima tahun (balita). Upaya peningkatan kualitas hidup anak harus dimulai sejak dini, yaitu sejak anak tersebut masih dalam kandungan hingga usia balita. Kesehatan anak sangat tergantung pada kesehatan ibu, terutama pada masa kehamilan, persalinan dan masa menyusui (Roesli, 2012:9).

Pola pemberian makan terbaik untuk bayi sejak lahir sampai anak berumur dua tahun meliputi: (a) memberikan ASI kepada bayi segera dalam waktu satu jam setelah lahir; (b) memberikan hanya ASI saja sejak lahir sampai umur enam bulan. Semua ibu dapat menyusui diukur dari permulaan pemberian ASI dalam jam pertama kehidupan bayi. Menyusui menurunkan risiko infeksi akut seperti diare, pnemonia, infeksi telinga, haemophilus influenza, meningitis dan infeksi saluran kemih. Menyusui juga melindungi bayi dari penyakit kronis masa depan seperti diabetes tipe 1 . Menyusui selama masa bayi berhubungan dengan penurunan tekanan darah dan kolesterol serum total, berhubungan dengan prevalensi diabetes tipe 2 yang lebih rendah, serta kelebihan berat badan dan obesitas pada masa remaja dan dewasa. Menyusui menunda kembalinya kesuburan seorang wanita dan mengurangi risiko perdarahan pasca melahirkan, kanker payudara, pra menopause dan kanker ovarium; (c) memberikan Makanan Pendamping ASI (MP-ASI) yang tepat sejak genap umur enam bulan; dan (d) meneruskan pemberian ASI sampai anak berumur dua tahun. Penerapan pola pemberian makan ini akan meningkatkan status gizi bayi dan anak serta mempengaruhi derajat kesehatan selanjutnya (Penjelasan Peraturan Pemerintah Nomor 33 tahun 2012:1).

ASI memiliki keunggulan dan keistimewaan sebagai nutrisi dibandingkan sumber nutrisi lainnya. Komponen makro dan mikro yang terkandung di dalam ASI sangat penting dibutuhkan pada tiap tahap pertumbuhan bayi. Komponen makro terdiri dari karbohidrat, protein dan lemak sedangkan komponen mikro adalah vitamin dan mineral (Yuliarti, 2012:23).

ASI juga mengandung zat antibodi yang disebut Imunoglobin A (IgA) yang berperan sebagai sistem pertahanan dinding saluran pencernaan terhadap infeksi. Bayi yang mendapatkan ASI eksklusif mempunyai kadar antibodi yang lebih tinggi dibanding dengan bayi yang mendapatkan susu formula. Oleh karena itu, daya tahan tubuh terhadap infeksi bakteri patogen pada bayi dengan ASI lebih besar dibanding dengan bayi dengan susu formula (Wiji, 2013:31).

Penerapan pola pemberian makan terbaik untuk bayi sejak lahir sampai anak berumur dua tahun tersebut belum dilaksanakan dengan baik khususnya dalam hal pemberian ASI eksklusif. Salah satu kendala dalam pemberian ASI eksklusif adalah karena ibu tidak percaya diri bahwa dirinya mampu menyusui dengan baik untuk mencukupi seluruh kebutuhan gizi bayi. Hal ini antara lain disebabkan karena kurangnya pengetahuan ibu, kurangnya dukungan keluarga serta rendahnya kesadaran masyarakat tentang manfaat pemberian ASI eksklusif. Selain itu juga karena kurangnya dukungan tenaga kesehatan, fasilitas pelayanan kesehatan, dan produsen makanan bayi untuk keberhasilan ibu dalam menyusui bayinya (Penjelasan Peraturan Pemerintah Nomor 33 tahun 2012:2). 
Berdasarkan data Kementerian Kesehatan 2013 (Kemenkes RI, 2013:23), prosentase ibu menyusui hanya ASI saja pada bayi umur 6 bulan meningkat dari $15,3 \%$ di tahun 2010 menjadi 30,2\% di tahun 2013. Di Provinsi Bengkulu pada tahun 2013 angka capaian pemberian ASI eksklusif adalah 43,3\% dan pada tahun 2014 meningkat menjadi 47\% (Profil Dinas Kesehatan Provinsi Bengkulu, 2014:43). Di Kabupaten Bengkulu Utara pada tahun 2013 didapatkan jumlah bayi usia 0-6 bulan yang menerima ASI eksklusif sebanyak 74,5 $\%$, turun dari tahun 2012 yang mencapai 76,94\% (Profil Dinas Kesehatan Kabupaten Bengkulu Utara, 2013:40). Data pemberian ASI eksklusif di Kecamatan Arga Makmur dari tahun 2012-2014 mengalami penurunan yaitu tahun 2012 sebesar 83,9\%, tahun 2013 menjadi 70,31\% dan tahun 2014 menjadi hanya $65,6 \%$ (Profil Puskesmas Arga Makmur, 2013:32).

Pemerintah Indonesia telah membuat Peraturan Pendukung Pemberian ASI yang dituangkan dalam Undang-Undang Kesehatan Nomor 36 tahun 2009 pasal 129 yaitu pemerintah bertanggungjawab menetapkan kebijakan dalam rangka menjamin hak bayi untuk mendapatkan air susu ibu secara eksklusif. Undang-Undang Kesehatan Nomor 36 tahun 2009 pasal 128 menyatakan : 1) Setiap bayi berhak mendapatkan air susu ibu eksklusif sejak dilahirkan selama enam bulan kecuali atas indikasi medis. 2) Selama pemberian air susu ibu, pihak keluarga, pemerintah daerah dan masyarakat harus mendukung ibu bayi secara penuh dengan menyediakan waktu dan fasilitas khusus. 3) Menyediakan fasilitas khusus sebagaimana dimaksud pada ayat 2 diadakan di tempat kerja dan tempat sarana umum.
Berdasarkan survey pendahuluan yang dilakukan oleh penulis melalui wawancara dengan Bidan Koordintaor di Puskesmas Arga Makmur pada bulan Oktober tahun 2015, diperoleh informasi bahwa program ASI eksklusif di Puskesmas Arga Makmur sudah berjalan namun belum bisa mencapai target sebesar 85\%, bahkan antara tahun 2012 sampai dengan tahun 2014 cenderung menurun. Hal ini dikarenakan masih kurangnya tenaga penyuluh tentang ASI Eksklusif oleh petugas puskesmas kepada masyarakat, susu formula lebih praktis dan ibu menyusui takut gemuk.

$$
\text { Pasal } 200 \text { Undang-Undang }
$$

Kesehatan Nomor 36 tahun 2009 mengancam setiap orang yang dengan sengaja menghalangi program pemberian ASI eksklusif akan dipidana penjara paling lama 1 tahun dan denda paling banyak seratus juta rupiah. Beberapa upaya untuk meningkatkan cakupan ASI eksklusif telah dilaksanakan dengan langkah kegiatan manajemen laktasi yang dilakukan : 1) Pada masa kehamilan dengan memberikan konseling laktasi, 2) Pada saat segera setelah persalinan dengan insiasi menyusu dini, 3) Pada masa neonatus dengan rawat gabung, 4) Pada masa menyusui selanjutnya dengan konseling untuk tetap memberikan ASI Eksklusif sampai 6 bulan, kecukupan gizi dan dukungan keluarga.

Peraturan Pemerintah Nomor 33 tahun 2012 pasal 2 menjelaskan bahwa pemberian ASI eksklusif bertujuan untuk : 1) menjamin pemenuhan hak bayi untuk mendapatkan ASI eksklusif sejak dilahirkan sampai dengan berusia enam bulan dengan memperhatikan pertumbuhan dan perkembangannya. 2) memberikan perlindungan kepada ibu dalam memberikan ASI eksklusif kepada bayinya dan 3) meningkatkan 
peran dan dukungan keluarga, masyarakat, pemerintah daerah, dan pemerintah pusat terhadap pemberian ASI eksklusif.

Peraturan Pemerintah Nomor 33 tahun 2012 pasal 5 mengatur tanggungjawab pemerintah daerah kabupaten/kota yang ada di Indonesia dalam pelaksanaan program ASI eksklusif, yaitu : 1) melaksanakan kebijakan nasional dalam rangka program pemberian ASI eksklusif. 2) melaksanakan advokasi dan sosialisasi program pemberian ASI eksklusif dalam skala provinsi. 3) memberikan pelatihan teknis konseling menyusui dalam skala provinsi. 4) menyediakan tenaga konselor menyusui di fasilitas pelayanan kesehatan dan tempat sarana umum lainnya dalam skala provinsi. 5) membina, monitoring, mengevaluasi, dan mengawasi pelaksanaan dan pencapaian program pemberian ASI eksklusif di fasilitas pelayanan kesehatan, satuan pendidikan kesehatan, tempat kerja, tempat sarana umum, dan kegiatan di masyarakat dalam skala provinsi. 6) menyelenggarakan, memanfaatkan, dan memantau penelitian dan pengembangan program pemberian ASI eksklusif yang mendukung perumusan kebijakan provinsi. 7) mengembangkan kerjasama dengan pihak lain sesuai dengan ketentuan peraturan perundangundangan. 8) menyediakan ketersediaan akses terhadap informasi dan edukasi atas penyelenggaraan pemberian ASI eksklusif dalam skala provinsi.

Peraturan Pemerintah Nomor 33 tahun 2012 tentang ASI eksklusif merupakan suatu kebijakan untuk mewujudkan pemenuhan hak bayi untuk mendapatkan ASI eksklusif sejak dilahirkan sampai dengan berusia 6 bulan dan memberikan perlindungan kepada ibu dalam memberikan ASI eksklusif kepada bayinya. Kebijakan tersebut dilaksanakan oleh Dinas Kesehatan Kabupaten Bengkulu Utara sebagai salah satu instansi yang memiliki kewajiban dan kewenangan dalam mengimplementasikan kebijakan Peraturan Pemerintah mengenai ASI eksklusif di semua kecamatan yang ada di Kabupaten Bengkulu Utara.

Dukungan pemerintah, baik pusat maupun daerah, penting dalam keberhasilan program ASI eksklusif. Pemerintah Kabupaten Bengkulu Utara hingga saat ini belum mempunyai sebuah kebijakan khusus tentang ASI eksklusif seperti Peraturan Daerah (Perda) dan Peraturan Bupati (Perbup). Landasan hukum yang digunakan adalah Surat Keputusan Menteri Kesehatan Republik Indonesia Nomor 450/MENKES/SK/IV/2004 tentang Pemberian Air Susu Ibu dan Peraturan Pemerintah Republik Indonesia nomor 33 tahun 2012 tentang Pemberian Air Susu Ibu Eksklusif.

Tidak adanya Peraturan Daerah atau Peraturan Bupati menyebabkan tidak adanya petunjuk pelaksanaan yang mengatur lebih lanjut tentang teknis operasional pelaksanaan ASI eksklusif di Kabupaten Bengkulu Utara. Hal ini bisa berpengaruh juga terhadap komitmen dan kepatuhan tenaga kesehatan dalam melaksanakan penyululuhan ASI eksklusif di masyarakat. Komitmen yang tepat serta kepatuhan terhadap aturan dari tenaga kesehatan merupakan hal yang penting dalam pelaksanaan program ASI eksklusif di Kabupaten Bengkulu Utara. Komitmen dari tenaga kesehatan dalam pelaksanaan program ASI eksklusif, di Kabupaten Bengkulu Utara khususnya bidan masih rendah, hal ini terbukti dengan masih adanya desa yang belum ada bidan desanya. Dalam upaya untuk mengetahui bagaimana implementasi kebijakan ASI eksklusif di Kecamatan Arga Makmur 
maka perlu dilakukan penelitian tentang implementasi Peraturan Pemerintah Nomor 33 tahun 2012 tentang ASI eksklusif di Kecamatan Arga Makmur.

\section{METODE PENELITIAN Jenis Penelitian}

Penelitian ini menggunakan desain penelitian kualitatif berjenis deskriptif. Penelitian kualitatif merupakan penelitian yang bertujuan memperoleh gambaran seutuhnya mengenai suatu hal menurut pandangan manusia yang diteliti, sehingga berkaitan dengan persepsi, ide, pendapat atau kepercayaan, yang tidak dapat diukur dengan angka (Moleong, 2011:31).

\section{Tempat Penelitian}

Penelitian ini dilakukan di Kecamatan Arga Makmur, Kabupaten Bengkulu Utara dikarenakan cakupan ASI eksklusif masih $65,6 \%$ belum mencapai $80 \%$ dari yang ditargetkan.

\section{Definisi Konsep}

Konsep adalah generalisasi dari sekelompok fenomena tertentu sehingga dapat dipakai untuk menggambarkan fenomena yang sama (Mardalis, 2004:45). Secara konsepsional implementasi program ASI Eksklusif adalah pelaksanaan pemberian ASI Eksklusif oleh ibu kepada bayi baru lahir dalam rangka pemberlakuan Peraturan Pemerintah Nomor 33 tahun 2012.

\section{Aspek Penelitian}

Implementasi

Peraturan

Pemerintah Nomor 33 tahun 2012 adalah tentang kebijakan program ASI Eksklusif pada prinsipnya merupakan perlindungan bagi bayi baru lahir untuk mendapatkan ASI secara utuh tanpa makanan lain sampai umur 6 bulan, adapun aspek penelitian ini sebagai berikut :

1. Komunikasi

Pelaksanaan kegiatan penyuluhan dan sosialisasi Peraturan Pemerintah Nomor 33 tahun 2012 tentang pemberian ASI eksklusif yang dilaksanakan oleh Dinas Kesehatan Bengkulu Utara dan Puskesmas Arga Makmur kepada masyarakat diwilayah kerja Puskesmas Arga Makmur.

2. Sumber Daya

Tersedianya tenaga, anggaran, fasilitas dan bahan informasi di Puskesmas Arga Makmur dalam kegiatan penyuluhan dan sosialisasi Peraturan Pemerintah Nomor 33 tahun 2012 tentang pemberian ASI eksklusif kepada masyarakat terutama ibu yang mempunyai bayi.

3. Sikap Pelaksana

Komitmen petugas di Puskesmas Arga makmur dalam kegiatan penyuluhan dan sosialisasi Peraturan Pemerintah Nomor 33 tahun 2012 tentang pemberian ASI eksklusif kepada masyarakat terutama ibu yang mempunyai bayi

4. Struktur Birokrasi

Tersedianya prosedur kerja (SOP) di Puskesmas Arga makmur dalam kegiatan penyuluhan dan sosialisasi Peraturan Pemerintah Nomor 33 tahun 2012 tentang pemberian ASI eksklusif dan ada tidaknya koordinasi dengan lintas program dalam lingkup Puskesmas Arga Makmur dan lintas sektor diluar Puskesmas Arga makmur, seperti : pemerintahan desa, ibu PKK, tokoh masyarakat dan tokoh agama.

\section{Informan Penelitian}

Informan dalam penelitian berjumlah 12 orang yang terdiri dari kepala Dinas Kesehatan 1 orang, Sekretaris Dinas Kesehatan 1 orang, 
Kepala Puskesmas 1 orang, Bidan Puskesmas 1 orang, Bidan Koordinator Puskesmas 1 orang, Ketua Ikatan Bidan Indonesia (IBI) 1 orang dan bidan desa 2 orang yang diambil secara purposive sampling mewakili bidan desa di Kecamatan Arga Makmur dan ibu menyusui 4 orang.

\section{Teknik Pengumpulan Data}

Teknik pengumpulan data merupakan langkah yang paling penting dalam penelitian, karena tujuan utama dari penelitian adalah mendapatkan data (Mardalis (2013:2). Untuk menjamin kualitas penelitiaan dan menghasilkan data yang tepat maka metode yang digunakan untuk mengumpulkan data dalam penelitian ini adalah wawancara, pengamatan, dokumentasi dan triangulasi :

1. Wawancara

Menurut Esterberg dalam Sugiyono (2013:231) wawancara merupakan pertemuan dua orang untuk bertukar informasi dan ide melalui tanya jawab, sehingga dapat dikontruksikan makna dalam suatu topik tertentu.

$$
\text { Pedoman wawancara }
$$

digunakan untuk mengingatkan peneliti mengenai aspek-aspek apa yang harus dibahas, juga menjadi daftar pengecek (check list) apakah aspek-aspek relevan tersebut telah dibahas atau ditanyakan. Aspek penelitian ditinjau dari peran bidan desa sebagai aspek tugas mandiri, tugas koloborasi dan tugas ketergantungan

2. Pengamatan

\begin{tabular}{lrr}
\multicolumn{1}{c}{ Sutrisno } & Hadi dalam \\
Sugiyono & $(2013: 145)$ \\
mengemukakan bahwa observasi \\
merupakan suatu proses & yang \\
kompleks, suatu proses & yang \\
tersusun dari berbagai proses
\end{tabular}

biologis dan psikologis. Dua di antara yang terpenting adalah prosesproses pengamatan dan ingatan.

Peneliti akan melakukan pengamatan tentang peran dan fungsi Dinas Kesehatan dan respon masyarakat untuk dapat memahami implementasi PP Nomor 33 tahun 2012 dengan wawancara dan hasil wawancara dapat dipahami dalam konteksnya. Pengamatan dilakukan peneliti terhadap subjek, perilaku subjek selama wawancara, interaksi subjek dengan peneliti dan hal-hal yang dianggap relevan sehingga dapat memberikan data tambahan terhadap hasil wawancara.

3. Dokumentasi

Menurut $\begin{array}{r}\text { Sugiyono } \\ \text { merupakan }\end{array}$
2013:240) dokumen sudah berlalu.
catatan peristiwa yang sudak
Dokumen bisa berbentuk tulisan,
gambar, atau karya-karya
monumental dari seorang. Dokumen
yang berbentuk tulisan misalnya
catatan harian, sejarah kehidupan,
ceritera, biografi, peraturan,
kebijakan.
Dokumentasi dalam penelitian ini yang berbentuk gambar misalnya foto, gambar hidup, sketsa dan lain-lain yang berfungsi sebagai bukti pelengkap pada saat wawancara dengan informan. Studi dokumen merupakan pelengkap dari penggunaan metode observasi dan wawancara dalam penelitian kualitatif.

4. Triangulasi

Dalam teknik pengumpulan data, triangulasi diartikan sebagai teknik pengumpulan data yang bersifat menggabungkan dari berbagai teknik pengumpulan data dan sumber data yang telah ada.

\section{Alat Bantu Pengumpulan Data}


Dalam mengumpulkan data, peneliti membutuhkan alat bantu (instrumen penelitian). Dalam penelitian ini peneliti menggunakan 3 alat bantu, yaitu pedoman wawancara, pedoman observasi dan alat perekam :

1. Pedoman wawancara

$$
\text { Pedoman wawancara }
$$

digunakan agar wawancara yang dilakukan tidak menyimpang dari tujuan penelitian. Pedoman ini disusun tidak hanya berdasarkan tujuan penelitian, tetapi juga berdasarkan teori yang berkaitan dengan masalah yang diteliti.

2. Pedoman Observasi

$$
\text { Pedoman observasi }
$$

digunakan agar peneliti dapat melakukan pengamatan sesuai dengan tujuan penelitian. Pedoman observasi disusun berdasarkan hasil observasi terhadap perilaku subjek selama wawancara dan observasi terhadap lingkungan atau setting wawancara, serta pengaruhnya terhadap perilaku subjek dan informasi yang muncul pada saat berlangsungnya wawancara.

3. Alat Perekam

Alat perekam berguna
sebagai alat bantu pada saat
wawancara, agar peneliti dapat
berkonsentrasi pada proses
pengambilan data tanpa harus
berhenti untuk mencatat jawaban-
jawaban dari subjek. Dalam
pengumpulan data, peneliti
menggunakan alat perekam setelah
terlebih dahulu mendapat izin dari
informan untuk mempergunakan alat
tersebut pada saat wawancara
berlangsung.

\section{Keabsahan Data}

Penelitian ini menggunakan pendekatan kualitatif. Peneliti melakukan empat kriteria keabsahan dan keajegan dalam penelitian kualitatif ini (Sugiyono, 2013:366) :

1. Keabsahan Konstruk

Keabsahan bentuk batasan berkaitan dengan suatu kepastiaan bahwa yang berukur benar- benar merupakan variabel yang ingin diukur. Keabsahan ini juga dapat dicapai dengan proses pengumpulan data yang tepat. Salah satu caranya adalah dengan proses triangulasi, yaitu teknik pemeriksaan keabsahan data yang memanfaatkan sesuatu yang lain di luar data sebagai pembanding terhadap data penelitian. Dalam penelitian ini pengujian keabsahan data menggunakan 3 triangulasi, yaitu (Sugiyono, 2013:368) :

a) Triangulasi Sumber

Menguji kredibilitas data dilakukan dengan cara mengecek data yang telah diperoleh melalui beberapa informan. Data yang diperoleh kemudian dideskripsikan dan dikategorisasikan sesuai dengan apa yang diperoleh dari berbagai sumber tersebut. Peneliti akan melakukan pemilahan data yang sama dan data yang berbeda untuk dianalisis lebih lanjut.

b) Triangulasi Teknik

Pengujian ini dilakukan dengan cara mengecek data kepada sumber yang sama dengan teknik yang berbeda, misalnya dengan melakukan observasi, wawancara, atau dokumentasi. Apabila terdapat hasil yang berbeda maka peneliti melakukan konfirmasi kepada sumber data guna memperoleh data yang dianggap benar.

c) Triangulasi Waktu 
Narasumber yang ditemui pada pertemuan awal dapat memberikan informasi yang berbeda pada pertemuan selanjutnya. Oleh karena itu, perlu dilakukan pengecekan berulang-ulang agar ditemukan kepastian data yang lebih kredibel.

2. Keabsahan Internal

Keabsahan

internal merupakan konsep yang mengacu pada seberapa jauh kesimpulan hasil penelitian menggambarkan keadaan yang sesungguhnya. Keabsahan ini dapat dicapai melalui proses analisis dan interpretasi yang tepat. Aktivitas dalam melakukan penelitian kualitatif akan selalu berubah dan tentunya akan mempengaruhi hasil dari penelitian tersebut. Walaupun telah dilakukan uji keabsahan internal, tetap ada kemungkinan munculnya kesimpulan lain yang berbeda.

3. Keabsahan Eksternal

Keabsahan ekternal mengacu pada seberapa jauh hasil penelitian dapat digeneralisasikan pada kasus lain. Walaupun dalam penelitian kualitatif memeiliki sifat tidak ada kesimpulan yang pasti, penelitiaan kualitatif tetapi dapat dikatakan memiliki keabsahan ekternal terhadap kasus-kasus lain selama kasus tersebut memiliki konteks yang sama.

4. Keajegan

Keajegan merupakan konsep yang mengacu pada seberapa jauh penelitian berikutnya akan mencapai hasil yang sama apabila mengulang penelitian yang sama, sekali lagi. Dalam penelitian ini, keajegan mengacu pada kemungkinan peneliti selanjutnya memperoleh hasil yang sama apabila penelitian dilakukan sekali lagi dengan subjek yang sama.
Hal ini menunjukkan bahwa konsep keajegan penelitian kualitatif selain menekankan pada desain penelitian, juga pada cara pengumpulan data dan pengolahan data.

\section{Teknik Analisis Data}

Dalam menganalisis data, peneliti melakukan lima tahapan sebagai berikut :

\section{Mengorganisasikan Data}

Peneliti mendapatkan data langsung dari subjek melalui wawancara mendalam. Data tersebut direkam dengan tape recorder dibantu alat tulis.

Kemudian dibuatkan transkipnya dengan mengubah hasil wawancara dari bentuk rekaman menjadi bentuk tertulis.

2. Pengelompokan Berdasarkan Kategori, Tema dan Pola Jawaban

Pada tahap ini peneliti kemudian kembali membaca transkip wawancara dan melakukan koreksi data yang relevan dengan pokok pembicaraan. Data yang relevan diberi kode dan penjelasan singkat, kemudian dikelompokkan atau dikategorikan berdasarkan kerangka analisis yang telah dibuat.

3. Menguji Asumsi atau Permasalahan yang Ada Terhadap Data

Pada tahap ini kategori yang telah didapat melalui analisis ditinjau kembali berdasarkan landasan teori yang telah dijabarkan dalam bab II, sehingga dapat dicocokkan apakah ada kesamaan antara landasan teoritis dengan hasil yang dicapai. Walaupun penelitian ini tidak memiliki hipotesis tertentu, namun dari landasan teori dapat dibuat asumsi-asumsi mengenai aspekaspek yang ada dalam penelitian. 
4. Mencari Alternatif Penjelasan Bagi Data

Pada tahap ini peneliti masuk ke dalam tahap penejelasan. Berdasarkan kesimpulan yang telah didapat dari kaitanya tersebut, penulis merasa perlu mencari suatau alternatif penjelasan lain tetang kesimpulan yang telah didapat.

5. Menulis Hasil Penelitian

Pada tahap ini peneliti menuliskan data-data hasil penelitian berdasarkan wawancara mendalam dan observasi dengan subjek. Proses dimulai dari data-data yang diperoleh dari subjek, dibaca berulang kali sehinggga penulis mengerti benar permasalahanya, kemudian dianalisis, sehingga didapat gambaran mengenai penghayatan pengalaman dari subjek. Selanjutnya dilakukan interprestasi secara keseluruhan, yang di dalamnya mencangkup keseluruhan kesimpulan dari hasil penelitian.

\section{HASIL PENELITIAN DAN PEMBAHASAN}

\section{HASIL PENELITIAN}

Pengambilan data dilakukan kepada informan di Dinas Kesehatan, Puskesmas Arga makmur dan di posyandu kepada ibu yang memiliki bayi, hasil penelitian sebagai berikut ;

\section{Aspek Komunikasi}

Upaya peran dan fungsi Dinas Kesehatan dalam program ASI eksklusif di Kecamatan Arga Makmur seperti disampaikan oleh responden IK sebagai berikut :

'......dengan adanya PP No 33
tahun 2012 tentang ASI
eksklusif, Dinas Kesehatan
berperan dalam menyampaikan
informasi tentang ASI eksklusif
kepada puskemas untuk

melakukan penyuluhan kepada masyarakat tentang pentingya pemberian ASI eksklusif bagi bayi setelah lahir. Pihak puskesmas melalui bidan koordinator akan mengumpulakn bidan desa sebagai tenaga para medis yang bertugas di desa, pada setiap posyandu atau pada kunjungan ibu hamil trimester 1 dan 2, bidan desa diharapkan akan memberikan penjelasan tentang manfaat ASI Eksklusif, kandungan-kandungan yang ada pada ASI dan kapan waktu pemberian ASI eksklusif. Manfaat ASI eksklusif antara lain untuk kekebalan, daya tahan tubuh tubuh dan membantu pencernaan bayi karena dalam kandungan ASI eksklusif terdapat Kolestrum, waktu pemberiannya sejak bayi umur 0 - 6 bulan tanpa pemberian makanan tambahan lainnya...... (Wawancara dengan IK, Februari 2016)

Begitu juga dengan responden NI menjelaskan tentang penyuluhan ASI Eksklusif sebagai berikut :

'PP No 33 tahun 2012 tentang ASI eksklusif mengharuskan Dinas Kesehatan melalui tenaga di puskesmas akan selalu memberikan penyuluhan tentang ASI eksklusif kepada masyarakat terutama ibu hamil, penyuluhan dilakukan kepada ibu hamil pada saat posyandu atau kunjungan ke rumah pada trisemester I dan trisemester II. ASI Eksklusif sangat penting untuk bayi, karena sangat bermanfaat bagi bayi baru lahir untuk daya tahan dan kekebalan tubuh bayi. Karena selain 
sebagai makanan dan minuman bayi ASI Eksklusif juga membantu kecerdasan bayi yang sifatnya murah, steril dan siap saji bagi bayi' (Wawancara dengan NI, Februari 2016).

Berdasarkan hasil wawancara dengan kedua responden tentang peran Dinas Kesehatan dalam implementasi ASI eksklusif, Dinas Kesehatan selalu memberikan penyuluhan kepada petugas kesehatan di puskesmas terutama bidan desa tentang ASI eksklusif, informasi ini akan diteruskan bidan desa yang dapat memberikan penyuluhan ASI eksklusif kepada ibu hamil pada kunjungan trisemester I dan trisemester II, dimana ASI eksklusif adalah pemberian ASI saja selama 6 bulan tanpa tambahan cairan apapun, seperti susu formula, jeruk, madu, air teh, air putih dan tanpa pemberian makanan tambahan lain, seperti pisang, bubur susu, biskuit, bubur atau nasi tim.

Implementasi PP No 33 tahun 2012 tentang ASI eksklusif oleh Dinas Kesehatan Kabupaten Bengkulu Utara dilakukan dengan melaksankan penyuluhan dan sosialisasi tentang manfaat ASI eksklusif kepada masyarakat terutama ibu-ibu yang memiliki bayi. Kegiatan ini dilakukan Dinas Kesehatan melalui tenaga kesehatan yang ada di puskesmas dengan cara komunikasi intrapersonal, dan komunikasi massa atau kelompok. Komunikasi intrapersonal dilakukan petugas pada saat ibu hamil melakukan pemeriksaan kehamilan dengan bidan desa, sedangkan komunikasi massa atau kelompok dilakukan petugas pada saat posyandu atau arisan kelompok dasawisma di desa.

\section{Aspek Sumber Daya}

Sumber daya manusia sebagai pelaksana program ASI eksklusif di Kecamatan Arga Makmur belum mencukupi, seperti penjelasan responden ES sebagai berikut :

'Puskesmas Arga Makmur
merupakan puskesmas yang ada
di Kecamatan Arga Makmur,
dimana semua desa dan
keluarahan yang ada di
Kecamatan Arga Makmur
merupakan wilayah kerja dari
Puskesmas Arga Makmur.
Dalam melaksanakan sosialisasi
dan penyuluhan program ASI
eksklusif di Kecamatan Arga
Makmur petugas di puskesmas
masih kekurangan tenaga
terutama bidan desa, hal ini
dikarenakan masih ada desa
yang tidak ada bidan desanya.
Tetapi kegiatan sosialisasi dan
penyuluhan program ASI
eksklusif terus dilaksanakan
sesuai dengan SDM yang ada'.
(Wawancara dengan ES,
Februari 2016).

Ketersediaan anggaran yang disediakan oleh Pemerintah Kabupaten Bengkulu Utara untuk implementasi program ASI eksklusif di Kecamatan Arga Makmur masih belum memadai, seperti yang dijelaskan oleh responden FS sebagai berikut :

'Untuk kegiatan program ASI eksklusif di Kecamatan Arga Makmur belum memiliki anggaran khusus dari Pemda kabupaten Bengkulu Utara, kegiatan program ASI eksklusif ini sementara menggunakan dana dari Bantuan Operasional Kesehatan (BOK) dan dana operasional kapitasi Jaminan Kesehatan Nasional (JKN). Walau bagaimanapun kegiatan 
sosialisasi dan penyuluhan program ASI eksklusif yang dilakukan Puskesmas Arga Makmur di desa-desa dalam Kecamatan Arga Makmur akan tetap berjalan karena mengikuti dari pada program yang telah ditentukan oleh pusat'. (Wawancara dengan FS, Februari 2016).

Ketersediaan fasilitas untuk implementasi program ASI eksklusif di Kecamatan Arga Makmur sudah mencukupi seperti penjelasan dari responden SA sebagai berikut :

'Alhamdulillah untuk fasilitas yang digunakan untuk kegiatan program ASI eksklusif baik di Puskesmas Arga Makmur maupun di desa sudah mencukupi. Dengan adanya fasilitas peralatan, seperti : boneka, instrument kesehatan, bidan kit dan bahan lainnya yang merupakan bantuan dari Kementerian Kesehatan. Memang bantuan tersebut sudah lama dapat dari Kementerian Kesehatan tapi masih memadai digunakan sebagai fasilitas untuk sosialisasi atau penyuluhan tentang ASI eksklusif terutama kepada ibuibu yang memiliki bayi, (Wawancara dengan SA, Februari 2016).

Bahan informasi untuk implementasi program ASI eksklusif di Kecamatan Arga Makmur sudah mencukupi, seperti yang dijelaskan oleh responden FS sebagai berikut :

'Bahan informasi untuk
sosialisasi atau penyuluhan
tentang ASI eksklusif di
Kecamatan Arga Makmur tidak
kekurangan, selalu tersedia.
Dinas Kesehatan maupun

organisasi profesi bidan selalu memberikan bahan tersebut. Dengan adanya internet juga membantu bagi petugas di Puskesmas Arga Makmur untuk melakukan kegiatan ASI eksklusif di masyarakat' (Wawancara dengan FS, Februari 2016).

Berdasarkan hasil wawancara dengan responden ES, FS dan SA dapat diketahui jika sumber daya di Puskesmas Arga Makmur dalam melakukan implementasi Peraturan Pemerintah Nomor 33 tahun 2012 tentang Pemberian ASI eksklusif di Kecamatan Arga Makmur untuk tenaga dan dana belum sepenuhnya ada, sedangkan untuk fasilitas dan bahan informasi sudah tersedia dikarenakan adanya bantuan dari Kementerian Kesehatan, Dinas Kesehatan Kabupaten Bengkulu Utara dan organisasi profesi Bidan yang ada di Kabupaten Bengkulu Utara.

Ketersediaan alat dan bahan untuk implementasi PP No 33 tahun 2012 tentang ASI eksklusif sudah tersedia, sedangkan sumber daya baik itu tenaga kesehatan maupun anggaran belum sepenuhnya mencukupi, masih ada desa yang belum ada bidan desa. Untuk mengatasi permasalahan ini puskesmas menggunakan dana Bantuan Operasioanl Kesehatan (BOK) dalam implementasi PP No 33 tahun 2012 sedangkan untuk tenaga bidan desa yang belum ada, puskesmas memberikan tugas kepada bidan desa terdekat untuk membantu kegiatan pelayanan kesehatan ibu dan anak termasuk melakukan penyuluhan dan sosialisasi tentang manfaat ASI eksklusif. 


\section{Aspek Sikap Pelaksana}

Upaya sikap petugas kesehatan untuk melakukan komitmen implementasi program ASI eksklusif di Kecamatan Arga Makmur seperti yang dijelaskan responden FS sebai berikut :

'Petugas di Puskesmas Arga Makmur sebagai pelaksana dalam implementasi Peraturan Pemerintah Nomor 33 tahun 2012 tentang Pemberian ASI eksklusif sudah melaksanakan tugas secara komitmen, petugas baik itu bidan yang ada di puskesmas induk maupun bidan desa selalu dan tak pernah berhenti memberikan penyuluhan tentang penting dan manfaat dari ASI eksklusif untuk bayi. Namun terkadang kendala yang ditemui petugas dari Puskesmas Arga Makmur, masih adanya ibu bayi yang belum mau menyusui anaknya saja sampai usia 6 bulan dengan alasan bayi belum kenyang jika minum ASI saja. Merubah perilaku masyarakat terutama ibu menyusui perlu waktu dan usaha penyuluhan yang terus menerus tanpa henti' (wawancara dengan FS, Februari 2016).

Selain itu juga responden ES juga menambahkan penjelasan dari responden FS sebagai berikut :

'Kita para bidan di Puskesmas Arga Makmur sebagai pelaksana implementasi

Peraturan

Pemerintah Nomor 33 tahun 2012 tentang Pemberian ASI eksklusif, selalu melakukan kegiatan baik itu sosialisasi maupun penyuluhan ke individu ibu hamil maupun ibu-ibu yang dating ke posyandu tentang manfaat dari ASI eksklusif untuk bayi. Tapi masih ada ibu yang memiliki bayi yang belum mau menyusui bayinya tanpa makanan lain sampai usia 6 bulan dengan alasan bayi belum kenyang jika minum ASI saja. Kendala ini sering ditemukan teman-teman bidan saat penyuluhan tentang ASI eksklusif" (wawancara dengan ES, Februari 2016).

Pemberian informasi program ASI eksklusif di Kecamatan Arga Makmur sudah sesuai dengan petunjuk, seperti dijelaskan oleh responden SA sebagai berikut :

'Informasi program ASI Eksklusif di Kecamatan Arga Makmur melalui tenaga kesehatan yang ada di Puskesmas Arga Makmur sudah sesuai dengan petunjuk dari Dinas Kesehatan Kabupaten Bengkulu Utara. Puskesmas dalam memberikan informasi program ASI eksklusif menggunakan metode ceramah, diskusi, tanya jawab seputaran tentang ASI eksklusif agar ibu yang punya bayi bisa memahami tentang pentingnya ASI eksklusif walau terkadang masih juga ditemukan ibu yang belum memberika ASI eksklusif pada bayinya' (wawancara dengan SA, Februari 2016).

Selain itu juga responden $\mathrm{NH}$ menjelaskan tentang petunjuk pemberian ASI eksklusif sebagai berikut :

'Merujuk dari Peraturan Pemerintah Nomor 33 tahun 2012 tentang pemberian ASI eksklusif, organisasi profesi bidan selalu mengharapkan baik bidan di puskesmas maupun bidan di desa melakukannya dengan pendekatan kekeluargaan, tidak menggurui dan menjelaskan secara rinci tentang ASI eksklusif sehingga ibu 
yang punya bayi mau memberikan ASI saja kepada bayinya sampai usia 6 bulan. Kendala dilapangan masih ditemukan ibu yang memberikan makanan lain selain ASI, hal ini perlu penjelasan secara bijaksana oleh petugas untuk menjelaskan jika usia bayi sampai 6 bulan cukup diberikan ASI saja tanpa makanan dan minuman lain' (wawancara dengan NH, Februari 2016).

Berdasarkan hasil wawancara dengan FS, ES, SA dan NH dapat diketahui bahwa bidan di puskesmas dan bidan desa telah melaksanakan komitmen dengan baik dalam menyampaikan program ASI eksklusif kepada masyarakat terutama ibu yang memiliki bayi. Kendala dilapangan masih ditemukan ibu yang memberikan makanan lain selain ASI, misalnya buah pisang. Hal ini perlu penjelasan secara bijaksana oleh petugas untuk menjelaskan jika usia bayi sampai 6 bulan cukup diberikan ASI saja tanpa makanan dan minuman lain.

$$
\text { Komitmen yang telah }
$$

dilaksanakan oleh bidan desa dalam implementasi PP No 33 tahun 2012 sudah dilaksanakan, namun kendala perilaku ibu-ibu yang masih meberikan makanan lain kepada bayinya selain ASI masih ditemukan oleh petugas di desa. Untuk mengatasi kendala tersebut petugas memperbanyak melakukan penyuluhan intrapersonal langsung kepada ibu yang memiliki bayi dan juga petugas melakukan kerjasama dengan tokoh masyarakat atau tokoh agama untuk terlibat dalam implementasi PP No 33 tahun 2012.

\section{Aspek Birokrasi}

Puskesmas Arga Makmur dalam melaksanakan program ASI eksklusif di Kecamatan Arga Makmur telah sesuai dengan prosedur kerja yang ada /SOP (Standar Operasional Prosedur), seperti yang dijelaskan responden FS sebai berikut :

'Puskesmas Arga Makmur dalam melaksanakan program ASI eksklusif mengikuti Peraturan Pemerintah Nomor 33 tahun 2012 tentang Pemberian ASI eksklusif, semua dilakukan mulai dari sosialisasi, diskusi kelompok ibu hamil, penyuluhan individu ibu hamil tentang pentingnya pemberian ASI eksklusif bagi bayi baru lahir sampai dengan usia 6 bulan' (wawancara dengan FS, Februari 2016).

Responden ES juga melengkapi penjelasan dari responden FS sebagai berikut :

'Setiap kunjungan ibu hamil ke bidan desa atau ke posyandu, petugas selalu memberikan penyuluhan tentang manfaat ASI eksklusif bagi bayi. Penyuluhan ini untuk melaksanakan Peraturan Pemerintah Nomor 33 tahun 2012 tentang Pemberian ASI eksklusif, hal ini sangat penting dikarenakan ASI sangat bermanfaat baik bagi ibu menyusui ataupun bagi bayi yang dilahirkan' (wawancara dengan ES, Februari 2016)

Berdasarkan hasil wawancara dengan FS dan ES dapat diketahui bahwa Puskesmas Arga Makmur dalam melaksanakan program ASI eksklusif di Kecamatan Arga Makmur telah sesuai dengan SOP yang ditetapkan oleh Kementerian Kesehatan.

Puskesmas Arga Makmur dalam melaksanakan program ASI eksklusif melakukan kerjasama lintas sektor dan lintas program seperti dijelaskan oleh FS sebagai berikut : 
'Puskesmas Arga Makmur dalam melaksanakan program ASI eksklusif melakukan kerjasama lintas sektor kepada Kecamatan Arga Makmur terutama ibu PKK yang ada di desa untuk ikut serta memberikan dukungan dalam pelaksanaan Peraturan Pemerintah Nomor 33 tahun 2012 tentang Pemberian ASI eksklusif. Lintas program dilakukan Puskesmas Arga Makmur bekerjasama dengan organisasi profesi bidan agar semua bidan terutama bidan desa untuk mendukung penuh program ASI eksklusif di Puskesmas Arga Makmur' (wawancara dengan FS, Februari 2016)

Responden SA juga menjelasakan pentingnya kerjasama lintas sektor dan lintas program dalam melaksanakan program ASI eksklusif sebagai berikut :

'Kerjasama lintas sektor dan kerjasama lintas program dalam melaksanakan program ASI eksklusif sangat diperlukan untuk mendapatkan dukungan dari pihak lain agar program ASI eksklusif dapat diterima oleh masyarakat dan berjalan dengan baik. Puskesmas Arga Makmur dalam melaksanakan program ASI eksklusif melakukan kerjasama lintas sektor kepada Kecamatan Arga Makmur dan lintas program dilakukan Puskesmas Arga Makmur bekerjasama dengan organisasi profesi bidan yang merupakan naungan para bidan desa' (wawancara dengan SA, Februari 2016)

Berdasarkan hasil wawancara dengan FS dan SA dapat diketahui bahwa Puskesmas Arga Makmur sudah melakukan kerjasama lintas sektor dan lintas program guna mendukung program ASI eksklusif di Kecamatan Arga Makmur.

Kerjasama lintas sektor dilakukan Puskesmas Arga Makmur dengan Kecamatan Arga Makmur terutama perangkat desa dan ibu-ibu PKK untuk ikut serta mengajak masyarakat terutama ibu-ibu yang mempunyai bayi agar memberikan ASI saja tanpa makanan lain sampai usia bayi 6 bulan. Puskesmas Arga Makmur juga melakukan kerjasama lintas sektor dengan tokoh masyarakat dan tokoh agama yang ada di desa untuk mendapatkan dukungan dan membantu petugas pada saat melakukan impelemantasi PP No 33 tahun 2012 di desa.

\section{Respon Ibu Tentang ASI Eksklusif}

ASI merupakan sumber nutrisi pada bayi. Komposisi yang terkandung di dalam ASI menunjang tumbuh kembang bayi apalagi terdapat kandungan antibodi alami yang dapat membantu dalam mencegah infeksi dan gangguan kesehatan pada bayi. Bahkan ASI lebih dikenal luas sebagai nutrisi yang lengkap yang dapat memberikan dukungan untuk pertumbuhan, kesehatan, imunitas dan perkembangan bayi sehingga dengan demikian pemberian ASI pada bayi sangat penting untuk diberikan. Pemberian ASI pada bayi minimal dengan memberikan ASI eksklusif, yaitu memberikan ASI tanpa makanan lainnya selama enam bulan pertama. Berkaitan dengan pemberian ASI eskslusif, peneliti melakukan wawancara dengan 4 ibu yang memiliki bayi, dengan hasil sebagai berikut : 
1) Pengertian ASI eksklusif menurut ibu RW adalah

'ASI eksklusif merupakan pemberian ASI tanpa memberikan makanan lain pada bayi yang berusia 0-6 bulan tidak boleh diberikan yang lain seperti susu bubuk, air teh atau lainnya. Pemberian ASI eksklusif diberikan hingga usia bayi 6 bulan' (wawancara dengan RW, Februari 2016).

Begitu juga dengan responden MA yang memberikan penjelasan tentang ASI esksklusif sebagai berikut :

'ASI eksklusif adalah pemberian ASI saja sampai dengan usia 6 bulan tanpa memberikan makanan lain pada bayi seperti susu formula, air manis atau lainnya. ASI eksklusif ini diberikan hingga usia bayi berusia 6 bulan' (wawancara dengan MA, Februari 2016).

2) Yang dilakukan petugas kesehatan kepada ibu agar memberikan ASI eksklusif pada bayi seperti penjelasan ibu ZA :

'Ibu bidan yang menolong saya melahirkan menganjurkan saya agar selalu memberikan ASI saja bagi bayi saya sampai berumur 6 bulan dan tidak boleh diberikan minuman lain' (wawancara dengan ZA, Februari 2016).

Begitu juga dengan ibu ID yang memberikan penjelasan tentang bagimana petugas kesehatan memberikan penyuluhan agar ibu memberikan ASI eksklusif pada bayi :

'Ibu bidan memberikan penjelasan kepada saya agar bayi selalu diberikan ASI saja tanpa ada makanan lain sampai bayi berusia 6 bulan. Bidan mengatan jika ASI dapat mencegah bayi terhindar dari penyakit, tetapi saya masih memberikan makanan lain kepada bayi saya sebelum usia 6 bulan, seperti pisang soalnya bayi saya kalo belum diberi pisang belum kenyang, (wawancara dengan ID, Februari 2016).

3) Peran petugas kesehatan dalam mempromosikan pemberian ASI eksklusif bagi bayi seperti penjelasan dari ibu MA :

'Ibu bidan sangat rajin memberikan penyuluhan kepada setiap ibu hamil yang periksa, jika melahirkan agar bayi diberikan ASI saja sampai usia 6 bulan. Di posyandu juga ibu bidan selalu mengingatkan ibu-ibu hamil ketika melahirkan bayinya diberikan asi saja sampai usia 6 bulan karena baik bagi bayi'. (wawancara dengan MA, Februari 2016).

Penjelasan serupa juga

disampaikan oleh ibu RW :

'Saat saya melahirkan ibu bidan memberikan penyuluhan kepada saya tentang pentingnya ASI bagi bayi sampai usia 6 bulan karena ASI berguna bagi bayi agar bayi terlindung dari penyakit'. (wawancara dengan RW, Februari 2016).

4) Manfaat memberikan ASI eksklusif pada bayi seperti penjelasan ibu ZA : 'ASI eksklusif memberikan manfaat pada bayi karena mudah dicerna apabila ketika pencernaannya belum begitu sempurna (dibawah usia 6 bulan). ASI juga dapat menyempurnakan tumbuh kembang bayi anda.Bahkan ASI dapat membuat bayi sehat dan juga cerdas. ASI eksklusif pada ibu juga memberikan manfaat. Pasca 
persalinan ASI eksklusif akan mempercepat pengecilan rahim semula. ASI eksklusif juga akan membantu dalam mengembalikan tubuh ibu setelah hamil. Dengan aktivitas menyusui maka timbunan lemak pada tubuh ibu akan dipergunakan untuk membentuk ASI sehingga berat badan ibu akan kembali stabil. (wawancara dengan ZA, Februari 2016).

Begitu juga dengan ibu MA yang memberikan penjelasan tentang manfaat ASI eksklusif :

'Dengan memberikan ASI eksklusif ada ikatan batin antara ibu dan anak akan lebih terjaga karena ibu dapat dengan mudah mengekspresikan sayang kepada anaknya. Dengan demikian ikatan batin semakin kuat. Begitupula dengan pemulihan kesehatan ibu yang semakin cepat ketika ibu memberikan ASI eksklusif pada bayi. Manfaat untuk ibu memberikan ASI eksklusif dapat mengurangi risiko kanker payudara dan juga kanker ovarium. Sedangkan manfaat ASI ekkslusif bagi bayi ASI dapat menjadi antibodi alami tubuh bayi terutama yang berhubungan dengan penyakit infeksi dan komposisi dan volume ASI akan disesuaikan dengan kebutuhan bayi. Anda tidak perlu khawatir akan berkurang sampai 6 bulan' (wawancara dengan MA, Februari 2016).

Berdasarkan hasil wawancara dengan keempat ibu dapat diketahui bahwa mereka sudah mengerti dan memahami tentang ASI eksklusif dan manfaatnya setelah diberikan penyuluhan oleh bidan tentang ASI eksklusif.

\section{PEMBAHASAN}

\section{Aspek Komunikasi}

Komunikasi merupakan proses penyampaian informasi dari komunikator kepada komunikan. Sementara itu, komunikasi kebijakan berarti merupakan proses penyampaian informasi kebijakan dari pembuat kebijakan kepada pelaksana kebijakan. Apabila tujuan dan sasaran suatu kebijakan tidak jelas bahkan tidak diketahui sama sekali oleh kelompok sasaran, maka informasi yang ingin disampaikan tidak akan diterima dengan baik oleh kelompok sasaran (Mulyadi, 2015:68-69).

Dinas Kesehatan Kabupaten Bengkulu Utara dalam implementasi PP Nomor 33 tahun 2012 tentang ASI eksklusif, akan selalu memberikan penyuluhan kepada petugas kesehatan di puskesmas terutama bidan desa tentang ASI eksklusif, informasi ini akan diteruskan bidan desa yang dapat memberikan penyuluhan ASI eksklusif kepada ibu hamil pada kunjungan trisemester I dan trisemester II, dimana ASI eksklusif adalah pemberian ASI saja selama 6 bulan tanpa tambahan cairan apapun, seperti susu formula, jeruk, madu, air teh, air putih dan tanpa pemberian makanan tambahan lain, seperti pisang, bubur susu, biskuit, bubur atau nasi tim. Komunikasi yang dilakukan Dinas Kesehatan kepada petugas puskesmas akan terus dilakukan untuk mengimplementasikan Peraturan Pemerintah Nomor 33 tahun 2012 tentang Pemberian ASI eksklusif. 


\section{Aspek Sumber Daya}

Sumber daya memiliki peranan penting dalam implementasi kebijakan. Jika para pelaksana kebijakan yang bertanggungjawab untuk melaksanakan kebijakan kurang mempunyai sumber-sumber daya untuk melaksanakan kebijakan secara efektif maka implementasi kebijakan tersebut tidak akan efektif. Sumber daya di sini berkaitan dengan segala sumber yang dapat digunakan untuk mendukung keberhasilan implementasi kebijakan. Sumber daya ini mencakup sumber daya manusia, anggaran, fasilitas, informasi dan kewenangan (Mulyadi, 2015:68-69).

Puskesmas Arga Makmur dalam melakukan implementasi Peraturan Pemerintah Nomor 33 tahun 2012 tentang Pemberian ASI eksklusif belum memiliki tenaga dan dana yang mencukupi terutama anggaran khusus dari pemda belum ada. Kegiatan ini menggunakan dana dari Bantuan Operasional Kesehatan (BOK) dan dana kapitasi Jaminan Kesehatan Nasional. Sedangkan untuk fasilitas dan bahan informasi sudah tersedia dikarenakan adanya bantuan dari Kementerian Kesehatan, Dinas Kesehatan Kabupaten Bengkulu Utara dan organisasi profesi Bidan yang ada di Kabupaten Bengkulu Utara.

\section{Aspek Sikap Pelaksana}

Kecenderungan perilaku atau karakteristik dari pelaksana kebijakan berperan penting untuk mewujudkan implementasi kebijakan yang sesuai dengan tujuan atau sasaran. Karakter penting yang harus dimiliki oleh pelaksana kebijakan misalnya kejujuran dan komitmen yang tinggi. Kejujuran mengarahkan implementor untuk tetap berada dalam asa program yang telah digariskan, sedangkan komitmen yang tinggi dari pelaksana kebijakn akan membuat mereka selalu antusias dalam melaksanakan tugas, wewenang, fungsi, dan tanggung jawab sesuai dengan peraturan yang telah ditetapkan. Sikap dari pelaksana kebijakan akan sangat berpengaruh dalam implementasi kebijakan. Apabila implementator memiliki sikap yang baik maka dia akan dapat menjalankan kebijakan dengan baik seperti apa yang diinginkan oleh pembuat kebijakan, sebaliknya apabila sikapnya tidak mendukung maka implementasi tidak akan terlaksana dengan baik (Mulyadi, 2015:68-69).

Petugas kesehatan di

Puskesmas Arga Makmur, baik bidan di puskesmas maupun bidan desa telah melaksanakan komitmen dengan baik dalam menyampaikan kepada masyarakat terutama ibu yang memiliki bayi tentang program ASI eksklusif, namun kendala di lapangan masih ditemukan ibu yang memberikan makanan lain selain ASI, misalnya buah pisang, madu, air kopi. Hal ini tentu saja menyebabkan angka cakupan ASI eksklusif di Puskesmas Arga Makmur belum mencapai target $80 \%$ sperti yang telah ditetapkan oleh Kementerian Kesehatan. Puskesmas Arga Makmu melalui petugas perlu menjelaskan jika usia bayi sampai 6 bulan cukup diberikan ASI saja tanpa makanan dan minuman lain.

\section{Aspek Birokrasi}

Struktur organisasi memiliki pengaruh yang signifikan terhadap implementasi kebijakan. Aspek struktur organisasi ini melingkupi dua hal yaitu mekanisme dan struktur birokrasi itu sendiri. Aspek pertama 
adalah mekanisme, dalam implementasi kebijakan biasanya sudah dibuat Standard Operational Procedur (SOP). SOP menjadi pedoman bagi setiap implementator dalam bertindak agar dalam pelaksanaan kebijakan tidak melenceng dari tujuan dan sasaran kebijakan. Aspek kedua adalah struktur birokrasi, struktur birokrasi yang terlalu panjang dan terfragmentasi akan cenderung melemahkan pengawasan dan menyebabkan prosedur birokrasi yang rumit dan kompleks yang selanjutnya akan menyebabkan aktivitas organisasi menjadi tidak fleksibel (Mulyadi, 2015:68-69).

Puskesmas Arga Makmur dalam melaksanakan program ASI eksklusif di Kecamatan Arga Makmur telah sesuai dengan SOP yang ditetapkan oleh Kementerian Kesehatan. Puskesmas Arga Makmur juga sudah melakukan kerjasama lintas sektor dan lintas program guna mendukung program ASI eksklusif di Kecamatan Arga Makmur.

\section{Respon Ibu Tentang ASI Eksklusif}

ASI merupakan sumber nutrisi pada bayi. Komposisi yang terkandung di dalam ASI menunjang tumbuh kembang bayi apalagi terdapat kandungan antibodi alami yang dapat membantu dalam mencegah infeksi dan gangguan kesehatan pada bayi. Dari kempat responden ibu ternyata satu ibu tidak memberikan ASI eksklusif pada bayinya, karena selain ASI ibu tersebut juga memberikan pisang kepada bayinya sebelum usia 6 bulan karena takut anaknya belum kenyang jika hanya minum ASI saja.

\section{PENUTUP}

\section{Kesimpulan}

Hasil penelitian dapat disimpulkan sebagai berikut :

1) Aspek komunikasi sudah dilaksanakan oleh Dinas Kesehatan Kabupaten Bengkulu Utara dalam implementasi PP Nomor 33 tahun 2012 tentang ASI eksklusif, dengan cara memberikan penyuluhan dan sosialisasi kepada petugas kesehatan di puskesmas terutama bidan desa tentang ASI eksklusif, informasi ini akan diteruskan oleh bidan desa kepada ibu hamil pada kunjungan trisemester I dan trisemester II yang melakukan pemeriksaan kehamilan secara teratur di desa.

2) Aspek Sumber daya di Puskesmas Arga Makmur dalam melakukan implementasi Peraturan Pemerintah Nomor 33 tahun 2012 untuk tenaga dan dana masih minim terutama anggran khusus dari pemda belum ada. Kegiatan menggunakan dana dari Bantuan Operasional Kesehatan (BOK) dan dana kapitasi Jaminan Kesehatan Nasional. Sedangkan untuk fasilitas dan bahan informasi sudah tersedia dikarenakan adanya bantuan dari Kementerian Kesehatan, Dinas Kesehatan Kabupaten Bengkulu Utara dan organisasi profesi Bidan yang ada di Kabupaten Bengkulu Utara.

3) Aspek pelaksana oleh petugas kesehatan di Puskesmas Arga Makmur, baik bidan di puskesmas maupun bidan desa telah melaksanakan komitmen dengan baik dalam pelaksanaan program ASI eksklusif, namun kendala di lapangan masih ditemukan ibu yang memberikan makanan lain selain ASI, misalnya buah pisang, madu, air kopi. 
4) Aspek birokrasi yang dilakukan oleh Puskesmas Arga Makmur sesuai dengan SOP yang telah ditetapkan oleh Kementerian Kesehatan. dan sudah melakukan kerjasama lintas sektor dan lintas program guna mendukung program ASI eksklusif di Kecamatan Arga Makmur.

5) Respon ibu tentang pemberian ASI eksklusif di Kecamatan Arga Makmur sudah memahami tentang ASI eksklusif dan manfaatnya setelah diberikan penyuluhan dan pehaman oleh bidan tentang ASI eksklusif, namun ada satu ibu yang tidak memberikan ASI eksklusif pada bayinya, karena selain ASI ibu tersebut juga memberikan pisang kepada bayinya sebelum usia 6 bulan.

\section{Saran}

Setelah melaksanakan dan mengamati hasil penelitian, maka peneliti dapat memberikan saran sebagai berikut :

\section{Aspek Akademis}

Hasil penelitian ini dapat memberikan manfaat bagi kepentingan akademis dalam memperkaya kajian ilmu Administrasi dan menambah referensi bagi peneliti lain untuk melakukan penelitian dengan aspek penelitian yang berbeda dan lebih spesifik.

\section{Aspek Praktis}

\section{Implementasi Peraturan} Pemerintah Nomor 33 Tahun 2012 Tentang Pemberian Air Susu Ibu Eksklusif di Kecamatan Arga Makmur agar selalu dilakukan oleh petugas dari Puskesmas Arga Makmur, baik oleh bidan yang ada di puskesmas maupun bidan yang ada di desa.

Meningkatkatn kerjasama lintas sektor dan lintas program untuk mencari dukungan agar program ASI eksklusif di Kecamatan Arga Makmur dapat meningkat.

Penyuluhan tentang memberikan ASI eksklusif pada bayinya sebelum usia 6 bulan agar dilakukan penyuluhan kepada ibu semenjak hamil sampai dengan melahirkan, sehingga nantinya ibu yang melahirkan memberikan ASI eksklusif pada bayinya.

\section{DAFTAR PUSTAKA}

Agustino, L. 2006. Dasar-Dasar Kebijakan Publik. Bandung: Alfabeta.

Buse, K. 2009, Making Health Policy (Membuat Kebijakan

Kesehatan), UGM, Yogyakarta.

Kusumanegara, S, 2010, Ilmu

Kebidanan, Kandungan dan

$K B$. Jakarta : EGC

Manuaba, 2008, Ilmu Kebidanan,

Kandungan dan KB. Jakarta :

EGC

Mardalis. 2004. Metode Penelitian (Suatu Pendekatan Proposal). Bumi Aksara, Jakarta.

Moleong. 2011. Penelitian Kualitatif. Remaja Rosdakarya, Bandung.

Mulyadi, D. 2015, Studi Kebijakan Publik dan Pelayanan Publik. Alfa Beta, Bandung.

Purwanto, A. 2012. Implementasi Kebijakan Publik. Yogyakarta : Gava Media.

Roesli, U. 2012, Mengenal ASI Eksklusif , PT Trubus Agriwidya, Jakarta

Sugiyono. 2014. Metode Penelitian Kuantitatif Kualitatif dan $R \& D$. Cetakan ke-20. Alfabeta, Bandung.

Wahab, S. 2008. Analisis Kebijaksanaan; Dari Formulasi ke Implementasi Kebijaksanaan Negara. Sinar Grafika, Jakarta. 
Wiji, R. 2013, ASI dan Panduan Menyusui, PT Nuha Medika, Yogyakarta

Winarno, B. 2007, Kebijakan Publik : Teori dan Proses, Media Pressindo, Yogyakarta
Yuliarti, N. 2012, Keajaiban ASI Makanan Terbaik Untuk Kesehatan, Kecerdasan dan Kelincahan, PT Andi, Jakarta 